\title{
Paleoecological assessment of cladoceran community dynamics in two subarctic peatlands
}

\author{
Jaakko Johannes Leppänen ${ }^{1}$ (D) Sanna Piilo ${ }^{1} \cdot$ Yuan Li $^{2} \cdot$ Hui Zhang ${ }^{1} \cdot$ Minna Väliranta $^{1}$
}

Received: 18 June 2018 / Accepted: 27 November 2018 / Published online: 4 December 2018

(C) The Author(s) 2018

\begin{abstract}
Crustacean community structure and dynamics are very well studied in lakes, rivers and oceanic systems but wetlands, where moisture conditions fluctuate, have not received equal attention in research. For example, cladoceran communities in peatland systems in the subarctic region have not been fully investigated. We used paleolimnological and paleoecological methods to study plant and cladoceran assemblages and the community dynamics in two subarctic peatlands, which differ in their hydrological characteristics. At the first site, Iitto, river floods introduce planktonic species to fen pools and the steep topography of the catchment induces rapid but relatively short flooding periods. Fluctuating environmental conditions result in a high amount of cladoceran resting stages in the samples. At the other site, Kaamanen, the cladoceran assemblage goes through clear directional changes, which could be attributed to changes in fen hydrology and ultimately to climatic changes during the past two millennia.
\end{abstract}

Keywords Peatland hydrology $\cdot$ Cladocera $\cdot$ Peat plants $\cdot$ Plant macrofossils $\cdot$ Climate $\cdot$ Flooding $\cdot$ Paleolimology

\section{Introduction}

Subarctic fens are challenging habitats for aquatic biota due to fluctuating water levels and a long season of ice and snow cover. In Northern Finland, many peatlands are flooded in spring due to snowmelt, which is followed by gradual shrinking of the open water area in late summer and autumn. Lakes in the northern Finnish Lapland are covered by ice from late October to early June. For aquatic animals, which are capable of inhabiting temporary wetland pools, rapid emergence and fast reproduction are key survival characteristics. Cladocera, a group of crustacean zooplankton, are known to bypass

Electronic supplementary material The online version of this article (https://doi.org/10.1007/s13157-018-1118-2) contains supplementary material, which is available to authorized users.

Jaakko Johannes Leppänen

jaakko.leppanen@helsinki.fi

Sanna Piilo

sanna.piilo@helsinki.fi

Yuan Li

ly12@1zu.edu.cn

Hui Zhang

hui.zhang@helsinki.fi drought or winter by diapause and are able to develop large populations in short period of time. The group is of pivotal importance in nearly all types of aquatic systems as they establish a link from primary producers to higher trophic levels. In addition, crustacean zooplankton are an important component in microbial loops, linking the group to aquatic carbon dynamics (e.g. Gaedge 2009; Matveev and Robson 2014). Moreover, cladocerans are regarded as an excellent indicator of environmental changes (Jeppesen et al. 2011) and the animals leave well preserved, identifiable remains upon death or molting, allowing the utilization of paleolimnological methods (Frey 1960). In addition to cladocerans, plant
Minna Väliranta

minna.valiranta@helsinki.fi

1 Environmental Change Research Unit (ECRU) Ecosystems and Environment Research Programme and Helsinki Institute of Sustainability Science (HELSUS), Faculty of Biological and Environmental Sciences, University of Helsinki, P.O. Box 65 (Viikinkaari 1), 00014 Helsinki, Finland

2 Key Laboratory of Desert and Desertification, Northwest Institute of Eco-Environment and Resources, Chinese Academy of Sciences, Lanzhou 730000, China 
macrofossils are a paleoecological indicator for past habitat changes and changes in carbon accumulation patterns in Subarctic peatlands (Väliranta et al. 2007, 2017, Swindles et al. 2015, Teltewskoi et al. 2016, Gałka et al. 2017).

Flood frequency and the longevity of inundation period are known to control zooplankton communities in floodplain ponds (Medley and Havel 2007) and cladoceran community structure in different types of lakes in northern Finnish Lapland has been studied numerous times (Rautio 1998; Korhola 1999; Siitonen et al. 2011; Leppänen et al. 2017). Despite this, long-term monitoring studies or paleolimnological studies assessing the cladoceran community dynamics in subarctic peatland pools have not been conducted before. Similarly to cladocerans, the plants in subarctic peatlands are exposed to cold winters and occasional floods. The plant community reflects the average water level, nutrient status and acidity in northern peatlands (Mauquoy and Geel 2007; Väliranta et al. 2007). Slow decomposition in waterlogged and anoxic peat permits the usage of plant macrofossils (i.e. undecomposed plant remains) in paleoecological studies (Mauquoy and Geel, 2007; Väliranta et al. 2007; Mathijssen et al. 2014).

Here, we use subfossil cladocera and plant macrofossils to study the cladoceran community structure and historical community dynamics in two subarctic fen environments which vary in their hydrological regimes. Because peatland characteristics are strongly controlled by hydrology (e.g. Holden 2006) and peatlands are regarded highly as important ecosystems in terms of carbon dynamics and climate change (e.g. Gallego-Sala et al. 2018), we feel that faunal the aquatic component of peatland systems deserves more attention in research. Our main research question is whether cladoceran community structure is related to moisture conditions in subarctic peatlands. Ultimately, we attempt to assess whether cladoceran paleolimnology holds potential as additional proxy tool for peatland moisture conditions. In addition, our results contribute to current knowledge on subarctic peatland biodiversity.

\section{Study sites}

Both study sites (Fig. 1 a-c and Table 1) are located in subarctic sporadic permafrost zone in Finnish Lapland. The Kaamanen region is an ecotone between subarctic and northern boreal zone, whereas Iitto belongs to subalpine region, where mountain birch is the dominant and sole tree species. Dry habitats of both study sites are characterised by species such as dwarf shrubs Betula nana, Empetrum nigrum, Vaccinium uliginosum, Rhododendron tomentosum and the herbaceous Rubus chamaemorus, bryophytes e.g. Polytrichum strictum, Dicranum spp. and S. fuscum. More minerotrophic and moister fen surfaces support taxa such as Salix spp., sedges such as Eriophorum vaginatum, E. angustifolium and Carex spp., C. limosa, Trichophofum spp. and different bryophytes Scorpidium scorpioides, Sphagnum species such as, Sphagnum balticum, S. majus, S. lindbergii and $S$. riparium.

Kaamanen peatland is a fen with strings, flarks, and nonpermanently frozen hummocks. The catchment area is characterized by relatively small elevation difference and numerous lakes and ponds. The southern end of the catchment is flat whereas the northern part is divided by esker formations. The nearest permanent waterbodies are a small, meandering brook at a distance of $\sim 50 \mathrm{~m}$, with an eutrophic riparian zone (Aurela et al. 1998) and a small lake (1.8 ha) at a distance of $\sim 300 \mathrm{~m}$ (Fig. 1c; Online Resource 1). The fen is located in an active groundwater region and there are numerous springs in the catchment suggesting a possibility for groundwater impact on water availability and water chemistry. According to available water chemistry data (OIVA database 2018), the lakes and rivers $(\mathrm{n}=5)$ in Kaamanen are nearly neutral $\mathrm{pH}(6.3$ 7.3), have relatively low nutrient concentrations (total phosphorus 4-12 $\mathrm{g} \mathrm{I}^{-1}$, total nitrogen 270-520 $\mathrm{g} \mathrm{g}^{-1}$ ) and low conductivity $\left(2-11 \mathrm{mS} \mathrm{m}^{-1}\right)$ and $\mathrm{Ca}\left(3.5-4 \mathrm{mg} \mathrm{l}^{-1}\right)$.

Iitto is a palsa peatland, i.e. a fen complex with individual peat mounds (palsas) that have been uplifted from the surrounding fen surface by permafrost upheaval. On the studied peatland, separate palsa mounds rise approximately two to four meters above the surrounding fen complex. The Iitto catchment is characterized by the steep slopes of fells Latnjavarit (720 m.a.s.l) and Coreheapmi (605 m.a.s.l) resulting an elevation difference of over $300 \mathrm{~m}$ between the lowest and the highest point. In addition, a small lake (1.7 ha) and River Könkämeno are located in the vicinity of the sampling site at distances of $100 \mathrm{~m}$ and $300 \mathrm{~m}$, respectively (Fig. $1 \mathrm{~b}$ and Online Resource 2). According to water level monitoring data recorded at Kaaresuvanto monitoring station, $50 \mathrm{~km}$ downstream, the water level at River Könkämäeno can fluctuate by 4 meters, reaching its highest level during May-July. Surface waters $(n=2)$ in the Iitto area are nearly neutral ( $\mathrm{pH}$ 6.8-7.1), oligotrophic (total phosphorus 3-6 $\mu \mathrm{g}$ $\mathrm{l}^{-1}$, total nitrogen $200-250 \mu \mathrm{g} \mathrm{l}^{-1}$ ) and electric conductivity values are low (1.9-3.9 $\mathrm{mS} \mathrm{m}^{-1}$ ) (OIVA database 2018).

\section{Methods}

\section{Coring and subsampling}

Two peat cores were collected with a box corer $(60 \mathrm{~cm} \mathrm{x} 7 \mathrm{~cm})$ in September 2016, one from each peatland. Selected Sphagnum covered high lawn habitats (less than $30 \mathrm{~cm}$ from the surrounding wet peatland surface) represent transitional habitat between wet fen and dry hummock. Selecting these microhabitats, enables us to assess how cladoceran communities response to changes in moisture conditions and changes in 


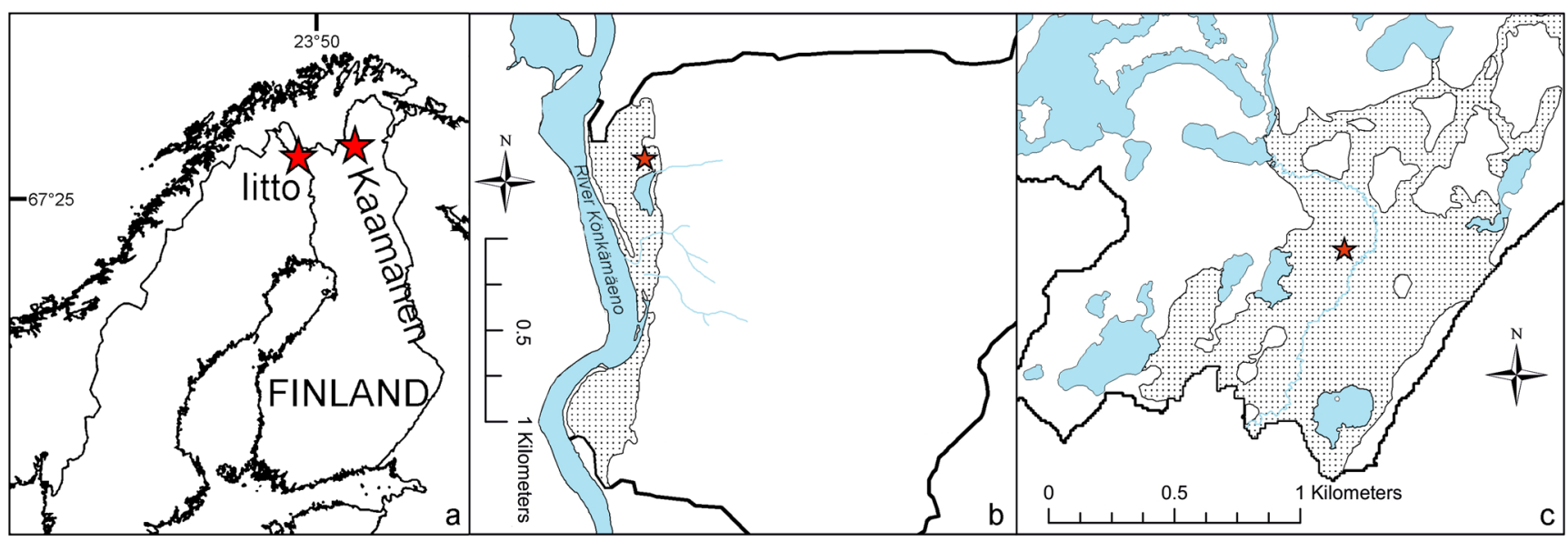

Fig. 1 a. Study site locations (stars) in northern Finland (a), Iitto (b) and Kaamanen (c) study sites. Dotted area represents the coverage of treeless peatland and thick line is the catchment boundary. Full catchment maps and elevation data are given in Online Resources (Kaamanen; Online

vegetation assemblages, when there is a shift from wet to dry. Peat cores were wrapped in plastic film and placed inside PVC gutters for transportation to the University of Helsinki, where they were stored in a freezer until further analysis. The $60-\mathrm{cm}$ long peat cores were defrosted and sliced in 1-cm intervals. The subsamples were stored in a cold room.

\section{Plant macrofossil analysis}

Plant macrofossil analysis was conducted at 2-cm intervals, increased to $1 \mathrm{~cm}$ for periods with prominent plant community changes. Volumetric $5 \mathrm{~cm}^{3}$ samples were rinsed through a $140-\mu \mathrm{m}$ mesh under running water. The residue on a sieve was analysed under a stereomicroscope for relative (\%) abundances. Further species level identification was conducted with a light microscope. The plant macrofossil analysis follows Mauquoy et al. (2010) and Väliranta et al. (2007). The highly decomposed plant matrix is called UOM, i.e. unidentified organic matter. Identification of plant macrofossils follows e.g. Viramo (1992); Mauquoy and Geel (2007); Laine et al. (2009). In addition, a plant reference collection was available.

Table 1 Geographical characteristics of study sites

\begin{tabular}{lrr}
\hline Study site & Kaamanen & \multicolumn{1}{l}{ litto } \\
\hline Latitude N (WGS84) & 2716.298 & 2125.327 \\
Longitude E (WGS84) & 6908.382 & 6843.428 \\
Altitude (m a.s.l.) & 139 & 400 \\
Peatland area $\left(\mathrm{km}^{2}\right)$ & 1.15 & 0.37 \\
Catchment area $\left(\mathrm{km}^{2}\right)$ & 30.5 & 6.5 \\
Elevation difference $(\mathrm{m})$ & 50 & 300 \\
Average temperature $\left({ }^{\circ} \mathrm{C}\right)$ & -0.4 & -1.9 \\
Average annual precipitation $(\mathrm{mm})$ & 472 & 487 \\
\hline
\end{tabular}

Resource 1 and Iitto; Online Resource 2). Maps are based on data obtained from open databases of Finnish Environmental Institute (http:// paikkatieto.ymparisto.fi/lapio/lapio flex.html\#) and from National Land Survey of Finland (https://tiedostopalvelu.maanmittauslaitos.fi/tp/kartta)

\section{Cladoceran analysis}

Cladoceran analysis was conducted using standard procedures published by Korhola and Rautio (2001). In short, approximately $1 \mathrm{~cm}^{3}$ of wet peat sample was heated $\left(90{ }^{\circ} \mathrm{C}\right)$ in $10 \%$ $\mathrm{KOH}$ bath for 1 hour and sieved through $50 \mu \mathrm{m}$ mesh. The residue was stained using safranin and slides were prepared with gelatin glycerol jelly. Cladoceran remains were identified and counted using a light microscope at 100-400 x magnification. Cladoceran identification and nomenclature was based on (Szeroczyńska and Sarmaja-Korjonen 2007). A minimum number of 100 individuals was counted from each sample. Cladoceran resting eggs (ephippia) were counted but species were not specified.

\section{Chronological analyses}

Chronology was established based on five accelerator mass spectrometry (AMS) radiocarbon ${ }^{14} \mathrm{C}$ dated samples (2 samples from Kaamanen core, 3 samples from Iitto core). ${ }^{14} \mathrm{C}$ samples were sent to Poznan Radiocarbon Laboratory (Poznan, Poland) and to the Finnish Museum of Natural History (LUOMUS, Helsinki, Finland). The dated samples were bulk peat, with roots and rootlets picked apart (Holmquist et al. 2016). Age-depth models were created using a bayesian BACON package (Blaauw and Christen 2011) using weighted mean ages and age-depth models in $\mathrm{R}$ version 3.4.3.

\section{Statistical analysis}

Analysis of Similarities (ANOSIM; Clarke 1993) was used to assess the similarities between cladoceran assemblages between sites. ANOSIM analysis was conducted using BrayCurtis dissimilarity matrix for square root transformed 
proportional data. Similarity percentages analysis (SIMPER; Clarke 1993) was used to quantify the overall average dissimilarity of cladoceran communities between sites and to pinpoint the species which contribute to the differences. SIMPER analysis was conducted on percentage data. Shannon H' diversity index (for cladocerans) was calculated using percentage data. Species richness (for cladocerans) was calculated using rarefaction method for count data (Birks and Line 1992). All analysis were conducted in the programme PAST (Hammer et al. 2001).

\section{Results}

\section{Chronology}

The deepest samples in Kaamanen $(57 \mathrm{~cm})$ and in Iitto (55 $\mathrm{cm}$ ) were dated to ca. 755 cal. BC (before Christ) and ca. 1425 cal. AD (Anno Domini), respectively, whereas the ages for samples above (Kaamanen $37 \mathrm{~cm}$ and Iitto $26 \mathrm{~cm}$ ) date to ca. 1365 cal. AD and ca. 1725 cal. AD, respectively. The peat accumulation rate for Kaamanen is approximately $0.1 \mathrm{~mm} \mathrm{y}^{-1}$ and for litto the peat accumulation rate is approximately $1 \mathrm{~mm}$ $\mathrm{y}^{-1}$. The ages provided from the age-depth models are included in the stratigraphies (Fig. 2 and Fig. 3) and raw data is given in Online Resource 1.

\section{Plant macrofossil results}

Abrupt and clear changes from wet Cyperaceous fen vegetation assemblages to drier ligneous and/or lawn/hummock vegetation are characteristic for both peat records. The results of selected taxa are presented in Figs. 2 and 3. Ombotrophic plant assemblages are not presented (Fig. 2 and Fig. 3) because the cladoceran remains disappear after the abrupt changes in vegetation and hydrology.

\section{Kaamanen}

The $57-\mathrm{cm}$ long record is characterised by two distinct phases in plant assemblages. The first phase from ca. $755 \mathrm{cal}$. BC to ca. $1530 \mathrm{cal}$. AD is dominated by Scorpidium scorpioides and Cyperaceous fen species (Limosa type Carex spp. and Eriophorum spp.). As the fen peat is humified, the proportion of UOM is high. Diatoms and Chrysophyceae cysts were detected until ca. 1340 cal. AD together with high percentage of Scorpidium scorpioides. Ombrotrophic S. fucum appears after ca. 1530 cal. AD and abruptly replaces the fen plant assemblages. Along with S. fuscum, S. capillifolium and S. magellanicum prevail until ca. 1815 cal. AD. Dark roots, indicating presence of (dwarf) shurbs, are found throughout this second phase. Vaccinium oxycoccos leaves and Empetrum nigrum leaves are abundant with few Andromeda polifolia leaves from ca. $1815 \mathrm{cal}$. AD towards present.

litto

The 55-cm long record is dominated by wet fen species until a sharp change at ca. 1725 cal. AD. Cyperaceae species Eriophorum spp. and limosa-type Carex remains occur with oligo- to mesotrophic $S$. lindbergii that usually thrives from pools to lawns (Laine et al. 2009). Around 1560 cal. AD S. lindbergii is replaced with Scorpidium scorpioides which is a typical fen taxon growing in wet hollows. Cf. S. platyphyllum is found until the plant composition shifts to ligneous and dwarf shrub remains around $1760 \mathrm{cal}$. AD. Peat

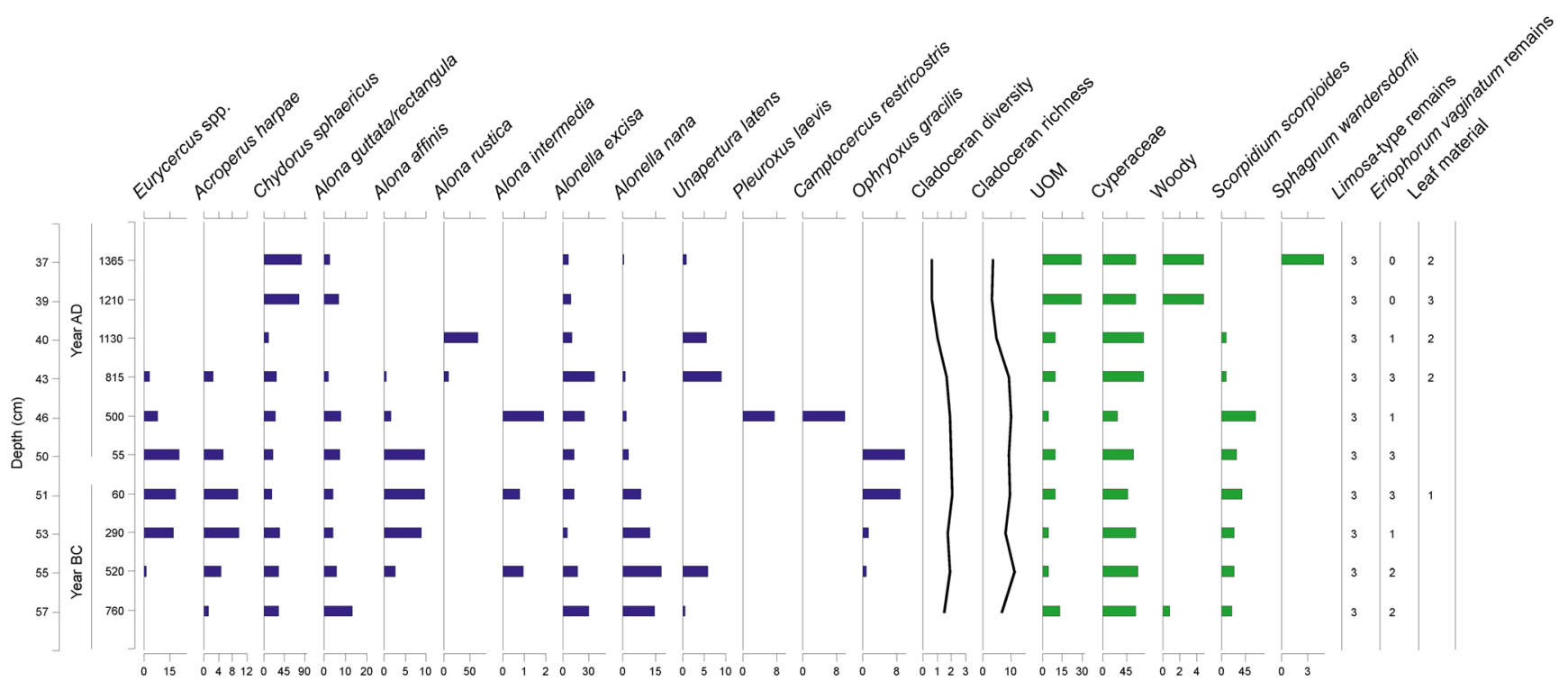

Fig. 2 Cladoceran and plant community stratigraphy in Kaamanen. In x-axis, all bar data is proportional data, whereas Limosa-type remains, Eriophorum vaginatum and leaf material abundances are presented as follows: $0=$ not found, $1=$ present/rare, $2=0$ occasional, $3=$ abundant 


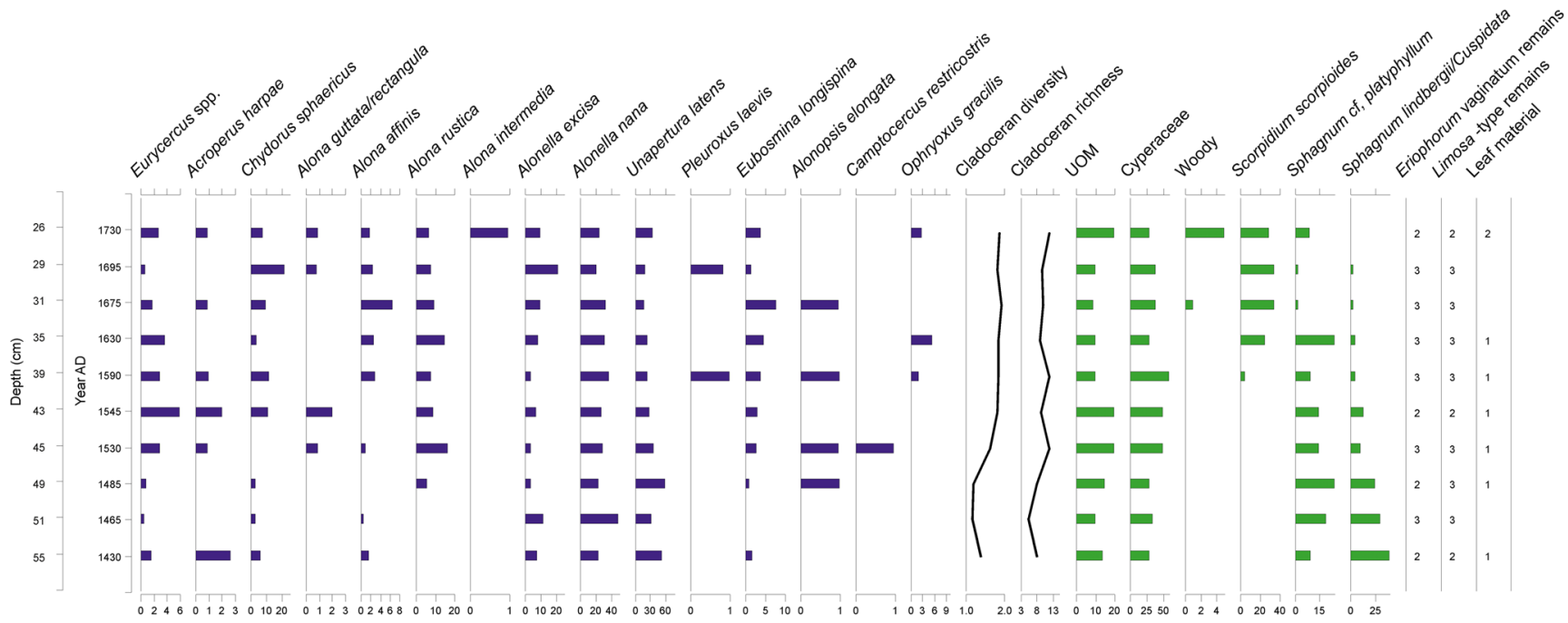

Fig. 3 Cladoceran and plant community stratigraphy in Iitto. In x-axis, all bar data is proportional data, whereas Limosa-type remains, Eriophorum vaginatum and leaf material abundances are presented as follows: $0=$ not found, $1=$ present/rare, $2=$ occasional, $3=$ abundant

layers with sedges and woody material are accompanied by high UOM. The phase with woody remains is characterised by high percentages of dwarf shrub roots and UOM, also Empetrum nigrum leaves are present. Around $1905 \mathrm{cal}$. AD Sphagna reappear with $S$. russowii (ombrotrophic to weakly minerotrophic) with Polytrichum strictum (from lawns to hummocks). Betula nana leaf remains are found throughout the ligneous phase to present.

\section{Cladoceran results}

Cladoceran remains were well preserved but relatively scarce in peat samples and in the top samples the remains became increasingly rare. An adequate number of subfossil remains for assemblage characterization ( 100 individuals; Kurek et al. 2010) was found from 10 samples from each site. A total of 15 taxa were identified from the samples ( $\min 3, \max 11$ in Kaamanen; min 6, max 12 in Iitto). Average Shannon $\left(\mathrm{H}^{\prime}\right)$ diversity for Kaamanen was 1.48 (0.6 to 2.0) and 1.67 (1.16 to 1.91) for Iitto. The most common species in Kaamanen were Chydorus sphaericus (average relative abundance 39 $\%$ SD $25 \%$ ) and Alonella excisa (average relative abundance $18 \%$ SD $11 \%$ ). The most common species in litto were Unapertura latens (average relative abundance $34 \%$ SD 14 $\%$ ) and Alonella nana (average relative abundance $30 \%$ SD 8 $\%)$. Most common species in both sites were present in all samples. The cladoceran communities in Kaamanen and Iitto are not similar (ANOSIM R 0.74, p<0.001) and according to SIMPER analysis, the overall average dissimilarity is 69 $\%$. The most important taxa which contributes to site-wise differences are U. latens $(23 \%), C$. sphaericus $(23 \%)$ and A. nana (17\%) (Online Resource 2). The number of cladoceran resting eggs varied in Kaamanen from 0 to 15 per 100 cladoceran individuals (average 6) and from 14 to 26 per 100 cladoceran individuals (average 23) in Iitto. The results are presented in Fig. 2 and 3.

\section{Kaamanen}

At the beginning of the record ( $57 \mathrm{~cm}$ level), the most abundant species are C. sphaericus, A.excisa and A. nana. The section between ca. $760 \mathrm{cal}$. BC $(57 \mathrm{~cm})$ and ca. $815 \mathrm{cal}$. $\mathrm{AD}(43 \mathrm{~cm})$ is characterized by high cladoceran diversity and declining abundance of $A$. nana. Beginning at ca. 815 cal. AD $(43 \mathrm{~cm})$ the cladoceran diversity starts to decline and the next sample at ca. $1130 \mathrm{cal}$. AD $(40 \mathrm{~cm})$ is characterized by nearly total domination of Alona rustica. In the following samples ca. $1210 \mathrm{cal}$. AD and ca. $1365 \mathrm{cal}$. AD $(39 \mathrm{~cm}$ and $37 \mathrm{~cm}$ ) the most abundant species is $C$. sphaericus.

\section{litto}

The cladoceran community in Iitto remains relatively stable through the record. The most distinct changes in the Iitto record are dated to ca. $1485 \mathrm{cal}$. AD $(49 \mathrm{~cm})$ and to ca. $1590 \mathrm{cal}$. $\mathrm{AD}(39 \mathrm{~cm}) .1485 \mathrm{AD}$ pinpoints the beginning of an increase in diversity $\left(\mathrm{H}^{\prime}\right)$ and an increase in proportional abundance of Eurycercus spp. and A. rustica. At ca. $1590 \mathrm{cal}$. AD (39 cm) and subsequent samples, Alona affinis exhibits a slight but visible increase in proportional abundance.

\section{Discussion}

\section{Cladoceran communities in Kaamanen and litto}

In general, cladoceran species detected in both study sites are common in Finnish Lapland lakes (Leppänen et al. 2017) and 
ponds (Rautio 1998). In addition, many of the species detected in both sites are regarded as common in peat bog ponds (Glime 2017) and some of the species (A. nana, C. sphaericus, A. excisa, A. affinis, Acroperus harpae) were reported during the late stages of transition from hilltop lake to an acidic ombrotrophic bog in southern Finland (Korhola 1992). Moreover, A. excisa and C. sphaericus have been reported to be common in shallow peatland pools in Romania (Battes et al. 2014), Hungary (Vad et al. 2012) and Bolivia (A. excisa and Chydorus breivilabris; Coronel et al. 2007) which further confirms the ability of those species to inhabit temporary shallow water environments. In both sites, the amount of cladoceran remains declines abruptly in top samples and probably reflects the formation of a palsa mound or peat hummock, as also recorded in the plant macrofossil assemblages. The increase in height results in disappearance of aquatic habitat and explains the lack of cladoceran remains. In addition, in both sites, cladoceran communities are clearly connected to hydrological characteristics of the environment. The relationship between plant and cladoceran communities is visible in the hydrological preferences of plant species as the samples with high cladoceran diversity occur systematically together with high abundance of Scorpidium scorpioides, which is reported to inhabit the wettest microhabitats in Kaamanen (e.g. Heikkinen et al. 2002).

While the cladoceran species assemblages in both sites are largely comprised of common and well known littoral species (e.g. A. nana, A. excisa and C. sphaericus), the largest specieswise difference between the sites is related to high proportional abundance of $U$. latens in Iitto. Interestingly, $U$. latens, is a relatively newly described species (Sarmaja-Korjonen et al. 2000) and its taxonomy and ecology are not well resolved. Another species worth mentioning is Eubosmina longispina, detected only in Iitto, which is a planktonic species and common in large and deep lakes. Thus, the explanation for the presence of E. longispina in Iitto is most probably related to the flooding of nearby River Könkämäeno. Based on satellite images, the river floods regularly and may therefore introduce planktonic species into the fen pools. The third distinct difference between the sites is the high number of cladoceran resting eggs in the Iitto samples. The large numbers of resting eggs is a result of intense sexual reproduction and reflects a high frequency of disturbance because cladocera survive ecological hardships (e.g. winter or drought) by diapause. The disturbances in Iitto are probably related to catchment characteristics, namely, to the river flooding and to melt water dynamics. Due to the steep topography of the Iitto catchment and the absence of lakes, melt water flooding is probably ephemeral, resulting in rapid variations in peatland water level. In contrast, the Kaamanen region is characterized by vast wetlands and numerous lakes which slow down the water flow increasing the longevity of the flood phase (Bring et al. 2016). In Kaamanen, the major flood lasts from May to June
(Väliranta et al. 2014) but flarks stay submerged longer (e.g. in 1995, until September; Heikkinen et al. 2002). Despite the direct contact to larger waterbodies, the absence of planktonic species in our samples suggests that the influx of cladocerans from upstream lakes into the Kaamanen fen pools is practically non-existent. This suggests that the flood water originates from regional snow melt rather than natural waterbodies upstream.

Thus, the major difference between the sites is therefore the longer flooding periods of the Kaamanen pool habitat during the growing season whereas the Iitto site is characterized by continuous influx of planktonic species and the fluctuating conditions.

\section{Cladoceran community dynamics in Kaamanen}

The most interesting section in the cladoceran record is dated between ca. 760 cal. BC $(57 \mathrm{~cm})$ and ca. $815 \mathrm{cal}$. AD $(43 \mathrm{~cm})$ where the diversity is highest and namely, where the relatively large bodied species Eurycercus, A. harpae, A. affinis and Ophryoxus gracilis occur in high proportional abundances while small-sized A. nana declines. The elevated abundance of $S$. scorpioides, which inhabits the wettest microhabitats in Kaamanen (Heikkinen et al. 2002), indicates wetter overall conditions between ca. 760 cal. BC and ca. 815 cal. AD. This time period corresponds to late Holocene climate cooling, which is characterized by intensified flooding in northern Scandinavia (Labuhn et al. 2018) and increasing water levels in Finnish Lapland lakes due to high effective moisture (Seppä and Birks 2001; Korhola et al. 2005). During wet conditions, the strong spring floods would have induced coalescence of multiple flarks resulting in larger pools with higher potential to harbor a more diverse cladoceran community (DiFonzo and Campbell 1988; Fig. 4). However, the same is probably true for invertebrate predators (e.g. copepods) and

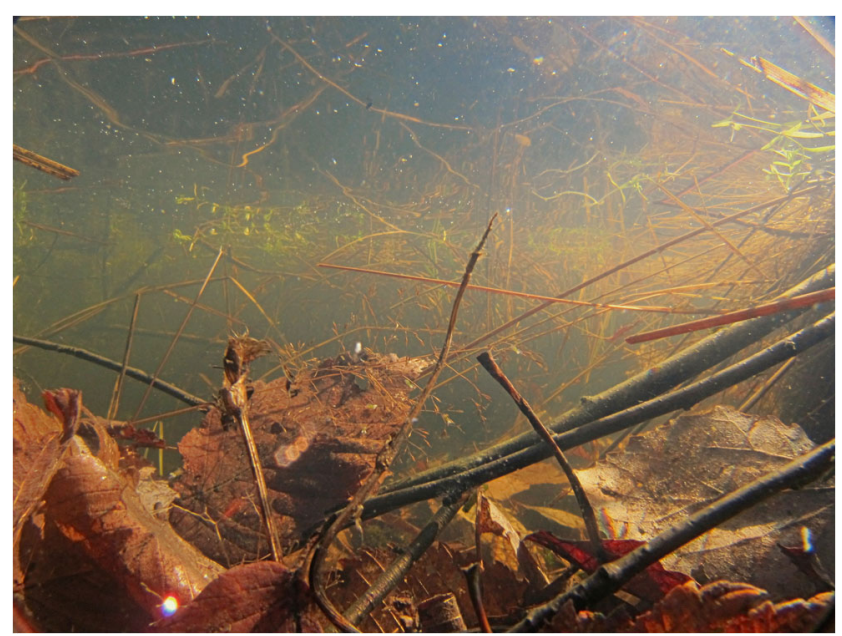

Fig. 4 During the high water level phase, the coalescent flarks provide increased availability of microhabitats for cladocerans 


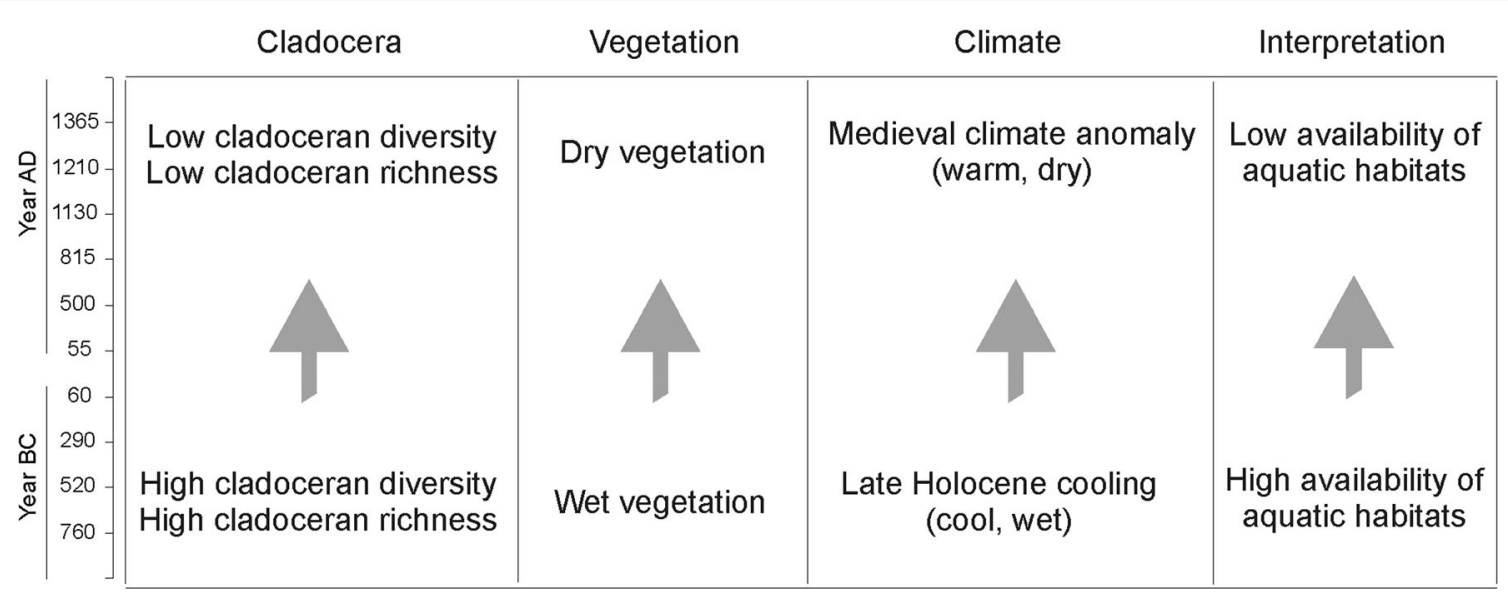

Fig. 5 Generalized temporal trajectories for Kaamanen study site

may explain the decline of $A$. nana, which, due to its small size, is the potential prey for many small predators (Gliwicz and Umana 1994). Another distinct change in the record is the rapid proportional increase and dominance of $A$. rustica at ca. $1130 \mathrm{cal}$. AD $(40 \mathrm{~cm})$ accompanied by decline in cladoceran diversity and species richness, and a simultaneous decrease in S. scorpioides abundance which suggests drier conditions. This may be caused by a relatively warmer climate and subsequently decreased effective moisture conditions during medieval climate anomaly roughly around 900-1200 AD (Esper et al. 2012). However, the dominant species at ca. $1130 \mathrm{cal}$. $\mathrm{AD}$ is A. rustica, which is reported to prefer groundwater habitats (stygophilic species) (Strayer 1988; Dumont 1995). Kaamanen is groundwater influenced and the momentary dominance of $A$. rustica suggests the possibility of changes in surface water chemistry related to groundwater discharge (Glaser et al. 1990). The dominating cladoceran species in the following samples dated to ca. $1210 \mathrm{cal}$. AD and ca. $1365 \mathrm{cal}$. $\mathrm{AD}$ (39 and $37 \mathrm{~cm}$, respectively) are C. sphaericus and A. excisa which are known to thrive in acidic lakes in e.g. Norway (Sandøy and Nilssen 1986) and are regarded to reflect slightly eutrophic conditions (Błędzki and Rybak 2016). Both species are common in temporary peatland pools. The reason for the dominance of these two species is thus probably related to decreased water level, microhabitat water chemistry changes, or both. Fen microhabitats may exhibit considerable spatial variation in surface water chemistry in northern Finland (Tahvanainen et al. 2002). Temporally, such differences can be induced by hydrological changes, e.g. when flarks are isolated from ground- or surface water source or vice versa. Other possible explanations for flark water chemistry changes include changes in river channel routing. Even though the meandering channels in north Lapland fens may exhibit rapid channel route changes (Kalliola and Puhakka 1988), traces of abandoned channels are not visible in the aerial photographs or LiDAR (Light Detection and Ranging) images. Moreover, when the aerial photographs from the 1990s (Aurela et al. 1998) were compared with the up-to-date aerial photography, the river channel routing seemed identical. Interpretation of shifts in cladoceran community, plant community and climate are illustrated in fig. 5 .

\section{Cladoceran community dynamics in litto}

Even though the annual variability in water level is probably very high due to Könkämäeno river floods and ephemeral melt water

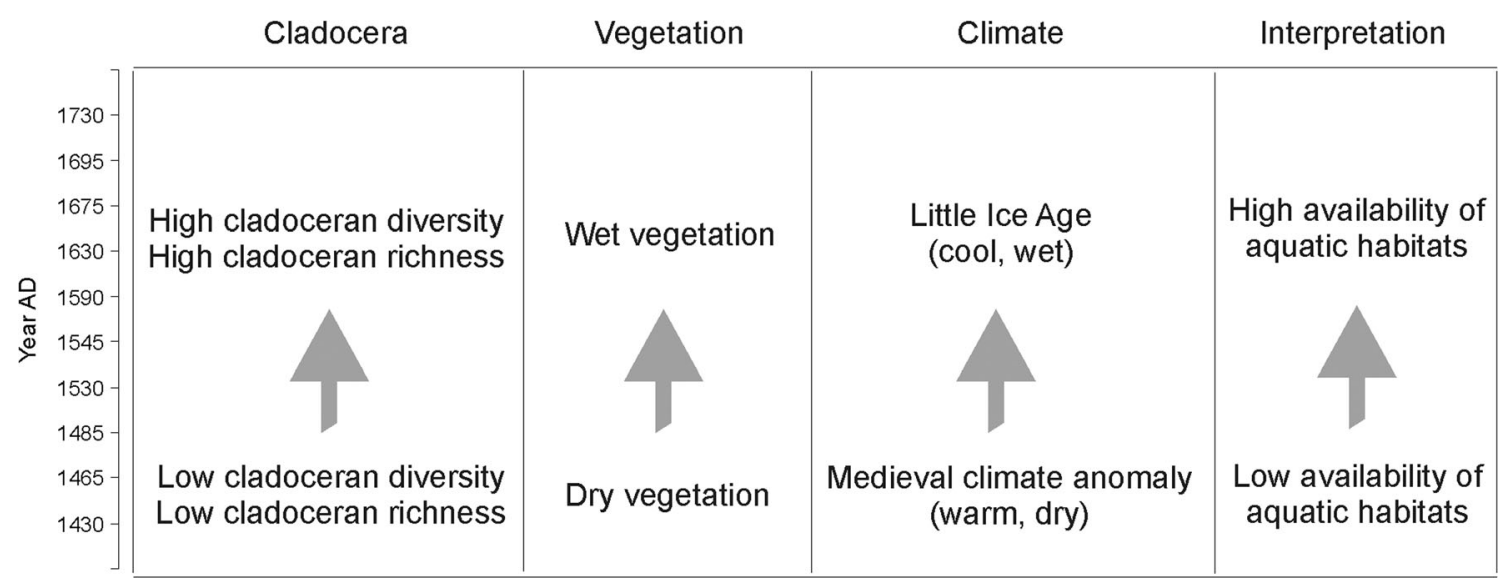

Fig. 6 Generalized temporal trajectories for Iitto study site 
flooding, the cladoceran community dynamics suggest stable change towards wetter conditions since ca. 1485 cal. AD (49 $\mathrm{cm})$. The abundance of $S$. scorpioides and cladoceran diversity increase synchronously from ca. $1485 \mathrm{cal}$. AD towards upper parts of the record suggesting increased water availability due to e.g. prolonged flooding, increased precipitation or other factors, which have increased the water volume in Iitto flarks. In addition, the planktonic $E$. longispina occurs in higher proportional abundance in samples above $49 \mathrm{~cm}$, which further suggests prolonged or more frequent river floods. However, any generalizations regarding temperature or precipitation trends for ca. 1485 cal. $\mathrm{AD}-\mathrm{ca} .1730 \mathrm{cal}$. AD are challenging due to chronological uncertainty. For example, it is possible that this section dates to a slightly warmer period between two cold periods of the Little Ice Age (LIA) in Northern Finnish Lapland identified by Luoto et al. (2017), or to a colder period of LIA. However, based on cladoceran community structure and the high abundance of wet indicators in our macrofossil data, it is very likely that this period was characterized by wet conditions. The interpretation of shifts in cladoceran community, plant community and climate are illustrated in fig. 6 .

\section{Conclusion}

Our results clearly indicate that cladoceran communities in subarctic peatlandsare relatively diverse. Species richness and diversity is related to water availability which, in turn is controlled mainly by climatic factors. This observation is important in terms of future climate change because the hydrological shifts may have high-magnitude impacts on aquatic diversity in subarctic peatlands. This study confirms the ability of crustacean zooplankton to thrive in harsh subarctic environments and identifies hydrological dynamics as the most important drivers of peatland cladoceran communities. In addition, our findings highlight the applicability of cladoceran remains in peatland studies and namely their potential as additional indicators of hydrological conditions. In addition, this potential could be further utilized in e.g. food web and carbon dynamics studies in flood prone peatland systems.

Acknowledgements Open access funding provided by University of Helsinki including Helsinki University Central Hospital. This study was funded by Academy of Finland, Tellervo and Juuso Walden Foundation and University of Helsinki Funds. In addition, H.Z. acknowledges China Scholarship Council (grant no. 201404910499) and Y.L. acknowledges China Scholarship Council (grant no. 201706180087).

Open Access This article is distributed under the terms of the Creative Commons Attribution 4.0 International License (http:// creativecommons.org/licenses/by/4.0/), which permits unrestricted use, distribution, and reproduction in any medium, provided you give appropriate credit to the original author(s) and the source, provide a link to the Creative Commons license, and indicate if changes were made.

\section{References}

Aurela M, Tuovinen J-P, Laurila T (1998) Carbon dioxide exchange in a subarctic peatland ecosystem in northern Europe measured by the eddy covariance technique. Journal of Geophysical Research 103: 11289-11301

Battes KP, Moldovan I, Sas A (2014) Planktonic microcrustaceans (Crustacea:Cladocera,Copepoda) from several protected peat wetlands, differing in trophic state. North-Western Journal of Zoology 10(supplement 1):S78-S86

Birks HJB, Line JM (1992) The use of rarefaction analysis for estimating palynological richness from Quaternary pollen-analytical data. The Holocene 2:1-10

Blaauw M, Christen JA (2011) Flexible paleoclimate age-depth models using an autoregressive gamma process. Bayesian Analysis 6:457474

Błędzki LA, Rybak JI (2016) Freshwater crustacean zooplankton of Europe. Springer International Publishing, Swizerland

Bring A, Fedorova I, Dibike Y, Hinzman L, Mård J, Mernild SH, Prowse T, Semenova O, Stuefer SL, Woo M-K (2016) Arctic terrestrial hydrology: A synthesis of processes, regional effects, and research challenges. Journal of Geophysical Research: Biogeosciences 121: 621-649. https://doi.org/10.1002/2015JG003131

Clarke KR (1993) Non-parametric multivariate analysis of changes in community structure. Australian Journal of Ecology 18:117-143

Coronel JS, Declerck S, Brendonck L (2007) High-altitude peatland temporary pools in Bolivia house a high cladoceran diversity. Wetlands 27:1166-1174

DiFonzo CD, Campbell JM (1988) Spatial partitioning of microhabitats in littoral cladoceran communities. Journal of freshwater ecology 4 : 303-313

Dumont HJ (1995) The evolution of groundwater cladoceran. Hydrobiologia 307:69-74

Esper J, Frank DC, Timonen M, Zorita E, Wilson RJS, Luterbacher J, Holzkämper S, Fischer N, Wagner S, Nievergelt D, Verstege A, Büntgen U (2012) Orbital forcing of tree-ring data. Nature Climate Change 2:686-866

Frey DG (1960) The ecological significance of cladoceran remains in lake sediments. Ecology 41:684-699

Gaedge U (2009) Trophic dynamics in aquatic ecosystems. In: Likens GE (ed) Plankton of inland waters. Elsevier, pp 344-350

Gałka M, Szal M, Watson EJ et al (2017) Vegetation Succession, Carbon Accumulation and Hydrological Change in Subarctic Peatlands, Abisko, Northern Sweden. Permafrost and Periglacial Processes 28:589-604

Gallego-Sala AV, Charman DJ, Brewer S et al (2018) Latitudinal limits to the predicted increase of the peatland carbon sink with warming. Nature Climate Change. https://doi.org/10.1038/s41558-018-02711

Glaser PH, Janssens JA, Siegel DI (1990) The response of vegetation to chemical and hydrological gradients in the Lost River Peatland, northern Minnesota. Journal of Ecology 78:1021-1048

Glime JM (2017) Arthropods: Crustacea - Copepoda and Cladocera. Chapter 10-1. In: Glime JM (ed) Bryophyte Ecology. Volume 2. Bryological Interaction. Michigan Technological University and the International Association of Bryologists. http:// digitalcommons.mtu.edu/bryophyte-ecology $2 /$. Accessed 20 March 2018

Gliwicz ZM, Umana G (1994) Cladoceran body size and vulnerability to copepod predation. Limnology and Oceanography 39:419-424

Hammer Ø, Harper DAT, Ryan PD (2001) PAST. Paleontological statistics software package for education and data analysis. Palaeontologia Electronica 4(1):9 
Heikkinen JEP, Maljanen M, Aurela M, Hargreaves KJ, Martikainen PJ (2002) Carbon dioxide and methane dynamics in a sub-Arctic peatland in northern Finland. Polar Research 21:49-62

Holmquist JR, Finkelstein SA, Garneau M et al (2016) A comparison of radiocarbon ages derived from bulk peat and selected plant macrofossils in basal peat cores from circum-arctic peatlands. Quaternary Geochronology 31:53-61. https://doi.org/10.1016/j.quageo.2015. 10.003

Holden J (2006) Chapter 14 Peatland hyrdology. In: Martini IP, Martinez Cortizas A, Chesworth W (eds) Developments in Earth surface processes. Volume 9: Peatlands: Evolution and records of environmental and climate changes. Elsevier, pp 319-346

Jeppesen E, Nõges P, Davidson T, Haberman J, Nõges T, Blank K, Lauridsen T, Søndergaard M, Sayer C, Laugaste R, Johansson L, Bjerring R, Amsinck S (2011) Zooplankton as indicators in lakes: a scientific-based plea for including zooplankton in the ecological quality assessment of lakes according to the European Water Framework Directive (WFD). Hydrobiologia 676:279-297

Kalliola R, Puhakka M (1988) River dynamics and vegetation mosaicism: a case study of the River Kamajohka, northernmost Finland. Journal of Biogeography 15:703-719

Korhola A (1992) The early Holocene hydrosere in a small acid hill-top basin studied using crustacean sedimentary remains. Journal of Paleolimnology 7:1-22

Korhola A (1999) Distribution patterns of Cladocera in subarctic fennoscandian lakes and their potential in environmental reconstruction. Ecography 22:357-373

Korhola A, Rautio M (2001) Cladocera and other Branchiopod crustaceans. In: Smol JP, Birks HJB, Last WM (eds) Tracking environmental change using lake sediments. Volume 4: Zoological indicators. Kluwer Academic Publishers, Dordrecht, pp 5-41

Korhola A, Tikkanen M, Weckström J (2005) Quantification of Holocene lake-level changes in Finnish Lapland using a cladocera - lake depth transfer model. Journal of Paleolimnology 34:175-190

Kurek J, Korosi JB, Jeziorski A, Smol P (2010) Establishing reliable minimum count sizes for cladoceran subfossils sampled from lake sediments. Journal of Paleolimnology 44:603-612

Labuhn I, Hammarlund D, Chapron E, Czymzik M, Dumoulin J-P, Nilsson A, Régnier E, Robydg J, von Grafenstein U (2018) Holocene hydroclimate variability in central Scandinavia inferred from flood layers in contourite drift deposits in Lake Storsjön. Quaternary 1:2. https://doi.org/10.3390/quat1010002

Laine J, Harju P, Timonen T, Laine A, Tuittila E-S, Minkkinen K, Vasander H (2009) The Intricate Beauty of Sphagnum Mosses - a Finnish Guide to Identification. Publications 39. University of Helsinki Department of Forest Ecology, Helsinki

Leppänen J, Siitonen S, Weckström J (2017) The stability of Cladoceran communities in sub-Arctic NW Finnish Lapland lakes. Polar Biology 40:2211-2223. https://doi.org/10.1007/s00300-017-2135-y

Luoto TP, Kivilä HE, Rantala MV, Nevalainen L (2017) Characterization of the medieval climate anomaly, little ice age and recent warming in northern Lapland. International Journal of Climatology. https://doi. org $/ 10.1002 /$ joc. 5081

Mathijssen P, Tuovinen J-P, Lohila A, Aurela M, Juutinen S, Laurila T, Niemelä E, Tuittila E-S, Väliranta M (2014) Development, carbon accumulation, and radiative forcing of a subarctic fen over the Holocene. The Holocene 24:1156-1166

Matveev V, Robson BJ (2014) Aquatic food web structure and the flow of carbon. Freshwater Reviews 7:1-24
Mauquoy D, Van Geel B (2007) Plant macrofossil methods and studies: Mire and Peat Macros. In: Elias SA (ed) Encyclopedia of Quaternary Science. Elsevier Science, Amsterdam, pp 2315-2336. https://doi. org/10.1016/B0-44-452747-8/00229-5

Mauquoy D, Hughes P, Van Geel B (2010) A protocol for plant macrofossil analysis of peat deposits. Mires and Peat 7:1-5

Medley KA, Havel JE (2007) Hydrology and local environmental factors influencing zooplankton communities in floodplain ponds. Wetlands 27:864-872

OIVA database (2018) Finnish environmental institute open database. syke.fi/avoindata. Accessed 10 Feb 2018.

Rautio M (1998) Community structure of crustacean zooplankton in subarctic ponds - effects of altitude and physical heterogeneity. Ecography 21:327-335

Sandøy S, Nilssen JP (1986) A geographical survey of littoral crustacea in Norway and their use in paleolimnology. Hydrobiologia 143:277286

Sarmaja-Korjonen K, Hakojärvi M, Korhola A (2000) Subfossil of an unknown chydorid (Anomopoda: Chydoridae) from Finland. Hydrobiologia 436:165-169

Seppä H, Birks HJB (2001) July mean temperature and annual precipitation trends during the Holocene in the Fennoscandian tree-line area: pollen-based climate reconstructions. The Holocene 11:527-539

Siitonen S, Väliranta M, Weckström J, Juutinen S, Korhola A (2011) Comparison of Cladocera -based water-depth reconstruction against other types of proxy data in Finnish Lapland. Hydrobiologia 676: $155-172$

Strayer D (1988) Crustaceans and mites (Acari) from hyporheic and other underground waters in southeastern New York. Stygologia 4:192207

Swindles GT, Morris PJ, Mullan D et al (2015) The long-term fate of permafrost peatlands under rapid climate warming. Scientific Reports 5:17951. https://doi.org/10.1038/srep17951

Szeroczyńska K, Sarmaja-Korjonen K (2007) Atlas of subfossil cladocera from central and northern Europe. Friends of the Lower Vistula society, Warzaw

Tahvanainen T, Sallantaus T, Heikkilä R, Tolonen K (2002) Spatial variation of mire surface water chemistry and vegetation in northeastern Finland. Annales Botanici Fennici 39:235-251

Teltewskoi A, Beermann F, Beil I et al (2016) 4000 Years of Changing Wetness in a Permafrost Polygon Peatland (Kytalyk, NE Siberia): A Comparative High-Resolution Multi-Proxy Study. Permafrost and Periglacial Processes 27:76-95

Vad CF, Horváth Z, Kiss KT, Ács É, Török JK, Forró L (2012) Seasonal dynamics and composition of cladoceran and copepod assemblages in ponds of a Hungarian cutaway peatland. International Review of Hydrobiology 97:420-434. https://doi.org/10.1002/iroh.201201441

Viramo J. (editor) (1992): Oulanka Reports, Suokasviopas. Oulanka Biological Station, University of Oulu, 11.

Väliranta M, Korhola A, Seppä H, Tuittila E-S, Sarjama-Korjonen K, Laine J, Alm J (2007) High-resolution reconstruction of wetness dynamics in a southern boreal raised bog, Finland, during the late Holocene: a quantitative approach. The Holocene 17:1093-1107

Väliranta M, Oinonen M, Seppä H, Korkonen S, Juutinen S, Tuittila E-S (2014) Unexpected problems in AMS ${ }^{14} \mathrm{C}$ dating of fen peat. Radiocarbon 56:95-108

Väliranta M, Salojärvi N, Vuorisalo A et al (2017) Holocene fen-bog transitions, current status in Finland and future perspectives. Holocene 27:752-764 